\title{
Os distintos e indistintos meios para viabilizar terminais de uso privativo no Porto de Santos
}

\author{
The distinct and indistinct ways to implement \\ private terminals in the Port of Santos
}

Fernanda Accioly Moreira [I]

\begin{abstract}
Resumo
No Brasil, o Estado sempre criou condições favoráveis para garantir a participação do setor privado nas transformações do espaço urbano, em especial em obras de infraestrutura de transporte e logística. Neste texto, buscamos discutir as disputas pela terra pública e, também, pelo modelo de gestão portuária, no contexto da expansão econômica nas primeiras décadas do século XXI. Ao delimitarmos o porto de Santos como nosso recorte territorial de análise, buscamos precisar os elementos, atores, agentes e conflitos de interesses presentes nessa disputa, bem como a forma pela qual eles se articulam em diferentes escalas. A abordagem transescalar aqui adotada como estratégica metodológica ancorou-se em relações de contínuas aproximações entre fundamentação teórica e imersão empírica. Nesse debate, a função social da terra pública, com oscilações ao seu papel ambiental e econômico, ganha centralidade.
\end{abstract}

Palavras-chave: terras públicas; Porto de Santos; terminais portuários; desenvolvimento urbano; zoneamento.

\begin{abstract}
In Brazil, the State has always created good conditions to guarantee the private sector's participation in the transformations of the urban space, especially in transport and logistics infrastructure works. In this article, we seek to discuss the disputes over public land and, also, over the port management model, in the context of the economic expansion at the beginning of the 21st century. By delimiting the Port of Santos as our territory of analysis, we aim to investigate the elements, players, agents and conflicts of interest present in the dispute, and how they articulate in different scales. The trans-scale approach adopted here as a methodological strategy was grounded on relations of continuous approximations between theoretical framework and empirical immersion. In this debate, the social function of public land, with oscillations in its environmental and economic role, gains centrality.
\end{abstract}

Keywords: public land; Port of Santos; port terminals; urban development; zoning. 


\section{Introdução}

No Brasil, o Estado garantiu o envolvimento do setor privado, tanto estrangeiro como nacional, em obras de infraestrutura logística, do setor de transportes, na promoção de habitação, entre outras (Seabra, 2015; Bonduki, 1998; Moreira, 2018). A relação entre Estado e setor privado sempre esteve presente nas transformações do espaço urbano, e a "disponibilização" de terras públicas pelo Estado e sua apropriação pelo setor privado, muitas vezes, foram realizadas de forma indevida. Neste artigo, interessa-nos debater os distintos mecanismos pelos quais o setor privado buscou viabilizar empreendimentos portuários de grande monta, em terras públicas federais, no contexto de forte pressão pela expansão da atividade logística durante o período do "milagrinho brasileiro" ${ }^{1}$ experimentado pelo País na primeira década do século XXI.

A importância estratégica da região do Porto de Santos, nosso objeto de análise, para a economia do País ganhou maior relevância, tendo em vista a exploração de petróleo nas camadas do pré-sal e a ampliação da atividade portuária atendendo às demandas do comércio exterior e do "efeito China". Mas, considerando a iminente saturação do porto público, observou-se a incursão do capital estrangeiro, abrindo uma nova frente para realização do capital excedente, disponível no mercado financeiro internacional. Neste artigo, buscamos analisar tal movimento, que almejava a implementação de greenfields projects ${ }^{2}$ nas áreas situadas ao fundo do estuário de Santos (canal Piaçaguera), fora do chamado porto organiza$\mathrm{do}^{3}$ - sendo a maioria, áreas de propriedade da União. Diferentemente dos terminais públicos arrendados dentro do porto organizado, para execução das modernas instalações dos novos terminais portuários de uso privativo (TUPs), seriam necessárias enormes intervenções no mar e na terra.

Como resultado deste trabalho, observou-se que, por meio de uma verdadeira "manobra de flanco", ${ }^{4}$ foi sendo construída uma ação, possivelmente coordenada, de diferentes atores em diversas frentes dentro das estruturas burocráticas e de poder político, nos diferentes níveis de governo, que tinha como objetivo enfraquecer o modelo de landlord port (em que privado é concessionário de terminais públicos) e emplacar o modelo dos TUPs. Para isso, foi necessário alterar as diretrizes e a legislação do setor portuário; transformar áreas de preservação ambiental em áreas de expansão portuária (modificando a Lei de Uso e Ocupação do Solo municipal e o Zoneamento Econômico e Ecológico - ZEE) da Baixada Santista); garantir aprovações e licenciamentos ambientais em diferentes níveis federativos; e, principalmente, assegurar o domínio das terras públicas, no caso, federais - não só como suporte material para construção de novas instalações portuárias, mas como instrumento de garantia, tanto das ações compensatórias decorrentes do processo de licenciamento ambiental, como para alavancar financiamentos públicos e privados necessários.

A abordagem transescalar, aqui adotada como estratégica metodológica, ancorou-se em relações de contínuas aproximações, em diferentes escalas, entre fundamentação teórica e investigação e imersão empírica - sendo, também, aderente a múltiplas frentes analíticas que perpassaram a leitura de processos administrativos, de legislações e demais normas nas três esferas federativas e de reportagens jornalísticas e a realização de entrevistas. 


\section{Para além do porto organizado de Santos, rumo às margens do canal Piaçaguera}

Os anos 1990 foram marcados pela desregulamentação e privatização de serviços estratégicos e pela abertura dos mercados nacionais sem que políticas compensatórias industriais, espaciais e tecnológicas fossem propostas. Segundo Klink (2013), o sucesso do Plano Real garantiu a estabilização da taxa de juros e, por consequência, a sustentação de um ambiente favorável aos negócios. Isso foi condição para a entrada do capital internacional na economia brasileira, reforçada pela agenda de desregulamentação financeira e pela vigência de uma taxa de juros extremamente alta, que servia para ancorar a sobrevalorização cambial.

A inserção do Brasil na lógica da economia global, por sua vez, deu-se a partir da "reprimarização" da economia (Pinto, 2013), em função do predomínio da exportação de bens primários, de baixo valor agregado, e do aniquilamento de boa parte do seu parque industrial, enquanto aos países centrais caberia o controle da criação e da produção de alta tecnologia. Apesar da adoção de medidas "ortodoxas" neoliberais na macroeconomia, segundo Klink (2013), o lançamento pelo governo federal do programa "Eixos Nacionais para a Integração e Desenvolvimento" (que norteou os consecutivos planos plurianuais "Brasil em Ação", de 1996/1999, e "Avança Brasil", de 2000/2003) pretendia uma reinserção parcial do Estado. Ainda conforme o autor, os programas não necessariamente visavam a corrigir distorções e instabilidades desencadeadas pela própria trajetória neoliberal dos anos 1990, mas sim aproveitar o interesse do capital internacional nessa nova conjuntura de abertura da economia brasileira. Tal estratégia que tinha como propósito conectar, através de corredores logísticos e informacionais, economias regionais competitivas (principalmente o agronegócio, a mineração e a siderurgia, e demais setores afins) com os principais centros de comando e controle, localizados dentro e fora do País, reforçou ainda mais uma tendência concentradora de ativos, infraestruturas e renda.

O Estado deixou de se responsabilizar diretamente pelos investimentos, mas continuou igualmente servindo a interesses de setores privados, agora através de diferentes formas de incentivo para atrair capitais nacionais e internacionais que estivessem potencialmente interessados em participar de processos de privatização de setores estratégicos da economia. A exemplo do modelo proposto ao setor portuário pela Lei de Modernização dos Portos, em 1993, que previu a privatização das Companhias Docas nos estados e um novo regime de concessão de terminais portuários e de regulação da mão de obra dentro do porto organizado.

Até os anos 2000, entretanto, ainda que o governo tivesse intentado atrair capitais nacional e internacional, não havia se conformado um ambiente suficientemente adequado e atrativo para induzir vultuosos investimentos privados e, assim, viabilizar empreendimentos portuários de grande relevância. Nem mesmo, no Porto de Santos, principal corredor de exportação do País, responsável por cerca de 25\% do total das exportações (Codesp, 2016).

Entre 2002 e 2006, a movimentação de carga no Porto de Santos cresceu cerca de $43 \%$ em peso, passando de 53 milhões para mais de 76 milhões de toneladas, acompanhando a tendência mundial de "conteinerização" 
(Gonçalves e Nunes, 2007, p. 257). Antes disso, porém, a Codesp ${ }^{5}$ já alertava para o fato de que o corredor de exportação mais importante do Brasil poderia entrar em colapso em 2006, caso não houvesse investimentos substanciais, pois a infraestrutura existente naquele momento só permitiria a operação de, no máximo, 70 milhões de toneladas (ibid., p. 260). Mesmo com deficiências e gargalos operacionais, a movimentação do Porto continuou registrando recordes até o ano de 2015. Tendência que não foi abalada, nem mesmo em meio à crise internacional de 2008 .

0 crescimento da atividade portuária, como mencionado, estava intrinsecamente ligado ao aumento do mercado externo e serviu para consolidar as diretrizes que já vinham sendo desenhadas no bojo dos programas de investimentos do governo FHC. Mas foi durante o governo Lula que esse processo ganhou dimensões exponenciais em função do "efeito China" (Pinto, 2013). A forte expansão da economia chinesa provocou transformações importantes na divisão internacional da produção e do trabalho. A China figurou-se, a partir dos anos 2000, como um enorme mercado consumidor de commodities (petróleo, minerais e produtos agrícolas, como soja, miIho, carne, entre outros) importadas de países da Ásia, África e América Latina, entre eles, o Brasil. Intensificando, assim, o processo de "reprimarização" do País que havia sido iniciado nos anos de $1990 .^{6}$

Outros fatores também contribuíram para o aumento da demanda da atividade portuária em Santos, como a necessária instalação de infraestrutura de apoio à exploração dos campos de petróleo e gás, recém-descobertos sob a camada do pré-sal na Bacia de Santos. Diante desse cenário e das previsões de crescimento futuro, era imprescindível atentar-se ao fato de que, caso o Porto de Santos mantivesse esse ritmo de crescimento, ao final de 2010, seria necessário dobrar sua capacidade operacional. $^{7}$

Segundo José Di Bella, então diretor presidente da Codesp em 2008, o porto público, mesmo sendo utilizado de forma competitiva e contando com novos terminais em execução, como o Brasil Terminal Portuário (BTP) ${ }^{8}$ e o Terminal de Granel Líquido da Stolthaven Santos, ${ }^{9}$ já contava "[...] com cerca de $79 \%$ do seu espaço, operando praticamente no limite de possibilidade de crescimento" (Di Bella, 2008, p. 9).

Dentro dos limites do porto organizado, a margem direita da fração insular do município de Santos estava tomada por instalações portuárias e, na margem esquerda, as áreas que potencialmente poderiam receber instalação de novos terminais se encontravam ocupadas por assentamentos precários (o Sítio Conceiçãozinha e o complexo Prainha, ambos situados no Guarujá). Essas áreas estariam disponíveis somente em médio prazo, sob a condição da conclusão do processo de urbanização e regularização fundiária, bem como do reassentamento de cerca de 1.962 famílias. Na época, a prefeitura municipal de Guarujá dispunha de recursos do Programa de Aceleração do Crescimento (PAC) do governo federal para financiar o Projeto Favela-Porto-Cidade, no qual estavam incluídos projetos e obras do empreendimento habitacional Parque da Montanha, no qual tais famílias deveriam ser realocadas.

Diante dessa conjuntura, as margens situadas ao fundo do estuário de Santos, fora do porto organizado e não urbanizadas, mais precisamente às margens do canal Piaçaguera, apresentaram-se como o território em disputa 
para a imprescindível e inadiável expansão portuária. Nesse momento, entretanto, esta não seria a única contenda em jogo. Estaria em disputa, também, o modelo portuário a ser emplacado nesse território "virgem" a ser explorado e capitaneado pelo setor privado. Uma disputa entre diferentes grupos econômicos, que, pela sua ação, enredaram-se nas teias burocráticas e políticas da relação com o Estado. Trata-se de um jogo que se estabeleceu internamente ao Estado, caracterizado por sua heterogeneidade e fragmentação, intra e entre os diferentes níveis federativos. E, em meio à "queda de braço", o acesso à terra pública da União entrou como fiel da balança, com poder de influenciar o resultado desse intrincado e belicoso jogo.

\section{O Projeto Barnabé-Bagres}

O projeto Barnabé-Bagres foi desenvolvido em 1999 pela empresa DTA Engenharia, a partir de contrato decorrente do edital público proposto pela Codesp em 1998, que tinha como objetivo estabelecer as "diretrizes de ocupação do Largo de Santa Rita, Ilha de Barnabé, Bagres e áreas adjacentes" (Di Bella, 2008, p. 9). Tratava-se de um estudo de viabilidade técnica, econômica, ambiental e de engenharia básica para o terminal portuário Barnabé-Bagres, um empreendimento de grande porte, pelo qual o Porto avançaria sobre áreas ambientalmente sensíveis, ainda não ocupadas pela atividade portuária, e que demandaria vultuosos recursos.

Ao longo da última década, o projeto não saiu do papel, mas esteve sempre presente na agenda portuária como o principal projeto de expansão do Porto de Santos. Sem dúvida seria necessário, para a efetivação de tal empreendimento, uma atuação devidamente coordenada e planejada de investimentos do poder público e da iniciativa privada.

Em 2008, entretanto, visando à efetivação desse projeto, e considerando os limites do porto organizado estabelecidos pelo decreto federal n. 4.333 de 2002, a Codesp solicitou à Agência Nacional de Transportes Aquaviários (Antaq) a ampliação de seus limites, prevendo a incorporação da Ilha de Bagres e áreas adjacentes. Naquele mesmo ano, foi firmado termo de parceria entre a Codesp e a empresa Santos-Brasil, já arrendatária do Terminal de Contêineres (Tecon), ${ }^{10}$ para elaboração de estudo de viabilidade pormenorizado para implantação do Complexo Barnabé-Bagres. Nessa oportunidade, buscando dar maior agilidade à conclusão dos estudos, a prefeitura de Santos anunciou sua participação na elaboração do projeto junto à Santos-Brasil, embora outras três arrendatárias de berços públicos tivessem divulgado interesse na elaboração dos projetos para tal complexo portuário. ${ }^{11}$

\section{TUPs ou não TUPs: o modelo portuário em disputa}

Ocorre que, em 2008, as negociações em torno da ampliação dos limites do porto organizado de Santos, que passavam por articulações para concretizar o projeto Barnabé-Bagres, saíram do plano local e entraram no bojo de discussões de espectro mais amplo sobre a regulação da atividade portuária, centradas em Brasília. Em tais discussões, os Terminais Portuários de Uso Privativo (TUPS) figuravam como elemento central na disputa a respeito de qual modelo deveria orientar a expansão 
da atividade portuária no País. Tratava-se de um embate não só entre projetos, mas entre interesses de diversos grupos econômicos, que afetaria diretamente a forma pela qual se daria o futuro do Porto de Santos.

Isso porque um conjunto de agentes privados, em função do crescimento das exportações e da atividade logística, vinha demonstrando maior empenho em investir no setor portuário, através da implantação e da operação de Terminais de Uso Privativo de contêineres, a fatia mais lucrativa entre as atividades do setor portuário. No caso de Santos, as áreas ao fundo do estuário, adjacentes ao porto organizado, em sua maioria de domínio da União, tornar-se-iam, a partir de então, foco de atenção para viabilizar esses empreendimentos, uma vez que a possibilidade de desenvolver novos projetos no porto público, como visto, estava quase saturada, e em pouco tempo se mostraria insuficiente para atender ao crescimento vertiginoso do comércio exterior brasileiro experimentado naquele período.

A expansão da atividade portuária pretendida pelos TUPs viabilizar-se-ia através da maior inserção da iniciativa privada pretendida desde a Lei de Portos de 1993, mas que, até então, não havia avançado de forma significativa. Em Santos, a exceção era a Empresa Brasileira de Terminais Portuários (Embraport), que levou quase duas décadas para entrar em operação, em meio a várias controvérsias. ${ }^{12}$ Isso porque a regulação do setor portuário, enquanto atividade econômica, era muito frágil, fato que permitia grande margem de arbitrariedade nas negociações entre poder público e agentes privados, gerando enorme insegurança jurídica para aqueles que pretendiam investir no setor e prejudicando, dessa maneira, o avanço da implantação de TUPs nos portos brasileiros.
Segundo Carlini (2008), presidente da Centronave, entidade que reúne empresas de comércio marítimo estrangeiras, os novos projetos de TUPs, fora do porto organizado, seriam desenvolvidos em áreas "virgens", livres de qualquer ocupação prévia, e, diferentemente dos terminais públicos arrendados no porto organizado, exigiriam enormes intervenções no mar e na terra, conforme as características de sua localização, além de modernas instalações e equipamentos necessários à movimentação de cargas, prioritariamente, conteinerizadas.

Os chamados greenfields projects demandariam, assim, pesados investimentos "disponíveis no mercado através de engenharia financeira de nível internacional, bancos ou fundos de investimentos que prezam muito pelos retornos financeiros que tais projetos devem prover [...]" (ibid.). Mas, para a efetivação de empreendimentos portuários de tal monta, era necessário atrair, além do capital privado, "[...] governos que demonstrem interesses no desenvolvimento de negócios que envolvam a cadeia logística. Estes investidores buscam retorno ao seu investimento em um ambiente regulado e estável" (ibid.; grifo nosso).

Era necessário, então, para criar esse ambiente estável e regulado, superar a ausência de previsão legal ${ }^{13}$ em relação às especificações sobre o tipo de carga permitido nas operações dos TUPs não tratadas pela Lei de Portos de 1993, em função da qual vinham sendo suscitadas inúmeras celeumas jurídicas sobre 0 assunto. ${ }^{14}$ Tal questão ganhou especial repercussão na mídia ${ }^{15}$ e no campo político, em um momento de crescimento das exportações.

Representantes de determinados setores econômicos, como a Confederação Nacional das Indústrias (CNI), a Centronave e grupos econômicos que vinham investindo pesado em 
novos terminais portuários de uso privativo, como, por exemplo, a Coimex (da Embraport, em Santos) e a LLX (de Eike Batista, dos terminais do Porto de Açu, estado do Rio de Janeiro), alegavam que estavam sendo prejudicados pela resolução n. 517 de 2005, da Antaq, que restringia a atuação dos TUPs, exclusivamente, à movimentação de cargas próprias. Em função disso, apoiavam o projeto de lei, em tramitação no Congresso Nacional, que previa que os TUPs poderiam movimentar cargas de terceiros sem quaisquer restrições, e sustentavam, ainda, a ideia de que o governo federal não poderia exigir licitação de terminais privativos, uma vez que sua implantação e operação seriam feitam em áreas privadas e fora do porto organizado (Valor Econômico, 2008).

Ocorre que os concessionários de berços públicos, dentro do porto organizado, reunidos pela Associação Brasileira dos Terminais de Contêineres de Uso Público (Abratec), colocaram-se firmemente contra esse movimento, alegando que seriam concorrencialmente prejudicados caso os terminais privativos viessem a transportar cargas de terceiros, uma vez que estes estariam desempenhando as mesmas funções dos terminais de uso público, mas sujeitos a uma regulação mais flexível, fato que, ao menos em tese, os tornaria menos competitivos do que os TUPs (ibid.).

Cabe mencionar que a Abratec representa, em âmbito nacional, empresas arrendatárias de terminais portuários de uso público, especializadas na movimentação de contêineres. Os principais terminais de contêineres do País, como as empresas Brasil Terminal Portuários - BTP, Libra Terminais Santos e Tecon-Santos, da Santos-Brasil Participações S/A, ligada ao Grupo Opportunity, operam no Porto de Santos e são associadas à Abratec. Para se ter a dimensão da força de sua representatividade no setor portuário, no ano de 2007, suas empresas foram responsáveis por $95 \%$ da movimentação de cargas em contêineres no País (Werneck, 2008).

Segundo matéria do jornal Valor Econômico (2008), Richard Klein, então vice- presidente do conselho de administração da empresa Santos Brasil, concessionária do Tecon-Santos, defendeu publicamente que os terminais de uso privativo misto, que movimentam carga própria e de terceiros, deveriam se enquadrar no marco regulatório em vigor, mediante Termo de Ajustamento de Conduto (TAC) ou via licitação de suas áreas (ibid.).

A Abratec chegou a apresentar, ao Supremo Tribunal Federal (STF), uma Arguição de Descumprimento de Preceito Fundamental (ADPF/139), na qual argumentou que a movimentação de cargas é um serviço público e que, como tal, deveria ser licitado. ${ }^{16} \mathrm{E}$, ainda, valendo-se do princípio jurídico do interesse público, alegou que os terminais de uso privativo, ao operar cargas de terceiros, poderiam colocar "[...] em risco a soberania nacional, ao permitir que, ao longo do tempo, os serviços portuários brasileiros passem a ser integralmente controlados por um pequeno grupo de investidores internacionais, submetidos a regime de direito privado e sem qualquer controle estatal brasileiro" (Brasil, 2008).

Não se pode deixar de mencionar que tais empresas, reunidas na Abratec, representavam interesses de grupos econômicos nacionais importantes, como o Opportunity e o Libra, com grande trânsito entre as estruturas institucionais e forte influência política, ${ }^{17}$ e que demonstraram sua capacidade de influenciar nas decisões do governo federal sobre $o$ assunto. 
Isso porque, depois de meses de discussões, o decreto presidencial n. 6.620, de outubro de 2008, apoiado em entendimentos anteriores, ${ }^{18}$ contrariou as expectativas dos novos investidores privados e estabeleceu que as operações de movimentação e armazenagem de cargas de terceiros seriam feitas, prioritariamente, por terminais e instalações de uso público, mediante concessão, e, portanto, submetidos à prévia licitação. E, ainda, que as instalações de uso privativo, outorgadas a particulares por autorização sem prévia licitação, poderiam realizar a movimentação e armazenagem de cargas de terceiros, apenas de modo secundário ou residual. Tal medida não foi um ato isolado do governo federal. Antes, o decreto presidencial n. 6.413, de março de 2008, excluiu do Plano Nacional de Desestatização de 1997 as companhias Docas e suas estruturas portuárias, ${ }^{19}$ contrariando a diretriz, apresentada no bojo das ações de privatização dos anos de 1990, de transferir integralmente a administração dos portos do País para o setor privado, não levada a cabo até então.

Nesse momento, as ações do governo federal convergiam no sentido de fortalecer o porto público, tido como instrumento estratégico para o desenvolvimento nacional. Foram ampliados investimentos públicos em intervenções de infraestrutura logística e portuária - no âmbito do Programa de Aceleração do Crescimento -, assim como em outros setores estratégicos da economia, a exemplo da indústria naval, pela retomada da construção de grandes estaleiros, e de plataformas navais e offshore para atender à expansão da produção de petróleo e gás, explorados em águas cada vez mais profundas e que exigiam a utilização de novas tecnologias, bem como para responder à demanda expressiva da movimentação de cabotagem e de carga internacional, especialmente para exportação de commodities, pelo aumento significativo da produção do agronegócio na região Centro-Oeste do País, mas também da indústria automobilística do Sudeste, entre outras atividades produtivas nacionais em crescimento no período do "milagrinho" econômico.

A frase de José Di Bella, diretor presidente da Codesp nesse período - "Não podemos esquecer que o porto público tem que atender os objetivos da nação e aí sim a iniciativa privada se encaixa" (2008; grifo nosso) -, expressa com clareza a diretriz do governo de fortalecer o porto público.

O conjunto de medidas adotadas demonstra certo centralismo nas decisões do governo em torno do setor portuário, que apontavam para a construção de um cenário que pretendia ser suficientemente atrativo para o setor privado nacional e internacional, algo imprescindível para o bom funcionamento do Porto e o atendimento às demandas impostas pela perspectiva desenvolvimentista do momento. Sem romper, todavia, com as estruturas de poder já estabelecidas no setor. Questiona-se, entretanto, se de fato tal modelo de gestão da atividade portuária, orquestrado pelo governo federal nesse momento, alcançaria as expectativas dos setores privados que aspiravam a realizar pesados investimentos na atividade portuária, nos moldes pautados pelo mercado internacional.

Fortes críticas de diversos setores econômicos e políticos alertaram para o fato de que a participação mais relevante e ampla do setor privado na atividade portuária estaria ameaça$\mathrm{da}$, uma vez que tais medidas restritivas representariam "obstáculos impostos à expansão da rede de terminais privativos de uso misto fora 
da área dos portos organizados" (Araújo Jr. e Guimarães, 2010, p. 57), e, ainda mais grave, poderiam ser caracterizadas como mecanismos de reserva de mercado, amparando "[...] um oligopólio privado que se fecha e ocupa o porto público" (Carlini, 2008).

\section{A manobra de flanco: como tornar o canal Piaçaguera um grande berço ${ }^{20}$ para os TUPS?}

Baixada a poeira, o que se viu, diferentemente das análises alardeadas, foi o avanço brutal do setor privado sobre as áreas livres do canal Piaçaguera, no contexto em que a atividade logística vinculada ao comércio exterior se tornara uma importante frente de realização do capital excedente, disponível em quantidade expressiva no âmbito global nesse período (Rolnik, 2017). A expressão "manobra de flanco" vem ao caso para elucidar o movimento que ocorreu em torno da apropriação de mecanismos institucionais e políticos, com o objetivo de tornar as margens do canal Piaçaguera utilizáveis para fins portuários e retroportuários, bem como garantir o acesso às terras públicas de domínio da União.

Uma ação combinada, possivelmente coordenada, de diferentes atores, em diversas frentes, dentro das estruturas administrativas e de poder político, nos diferentes níveis de governo, que tinha como objetivo reverter as diretrizes governamentais sobre o setor portuário e emplacar o modelo dos TUPs nas áreas situadas ao fundo do estuário de Santos, acima dos limites do porto organizado, na porção continental do município de Santos. Um conjunto de distintos e indistintos meios, que avançaram sobre os limites da legalidade e da moralidade, para viabilizar os TUPs no Porto de Santos, conforme veremos a seguir.

\section{O porto é escala!}

\section{Rumo às novas fronteiras}

No ano de 2010, o Plano de Diretor e de Zoneamento do Porto de Santos estava sendo revisado com base em estudo elaborado pelo Banco Interamericano de Desenvolvimento (BID). Tal plano, denominado Master Plan, projetou que a capacidade do Porto de Santos triplicaria até 2024. Além disso, estabeleceu que o perfil de carga movimentada deveria ser mantido (granéis sólidos, granéis líquidos, contêineres), acrescentando apenas a presença de plataformas offshore para atender às necessidades da exploração de óleo e gás, que tão logo se iniciaria na Bacia de Santos.

Em resposta à tendência mundial de operar grandes armadores, que apresentam maior envergadura e calado, o Plano destacou como principal diretriz a necessidade de adotar o novo conceito dos megaterminais portuários, ancorado no ganho de escala e redefinição da dimensão das instalações portuárias, objetivando maior capacidade e diminuição de custos operacionais. Conforme afirmou o então ministro dos portos, Pedro Brito.

O objetivo é evitar a colcha de retalhos feita por pequenos terminais que provocam fuga dos grandes armadores. $A$ escala do negócio portuário não é decisão do porto, mas do mercado. E o que garante a escala é o papel do governo no disciplinamento do negócio, evitando a competição entre uma série de 
pequenos terminais que não tenham escala nem eficiência. (Valor Econômico, 2010b; grifos nossos)

Contradizendo a expectativa de governo compartilhada anos antes, a de que os interesses da iniciativa privada se encaixariam nos interesses da nação, a nova "escala de negócio", pautada pelo mercado mundial dos grandes armadores, entra no discurso institucional da pasta de Portos, a partir de duas frentes: pela redefinição das estruturas existentes quando da renovação dos contratos de arrendamento, buscando agregar terrenos vizinhos e remodelar os berços de atracação e as áreas de armazenagem de acordo com a nova lógica; e pela ampliação da atual fronteira do Porto de Santos a partir da implantação do Projeto Barnabé-Bagres - mantido entre as diretrizes prioritárias do PDZPS, em debate no ano de 2010.

Entretanto, para a concretização dessa nova diretriz de mercado trazida pelo BID e, em certa medida, incorporada pelo governo federal, ampliar somente os limites do porto organizado de Santos não seria suficiente para atender à "escala de negócio" pretendida pelo mercado mundial. Seria necessário avançar sobre outras fronteiras.

\section{A lei de uso e ocupação do solo de Santos e o zoneamento ecológico-econômico da Baixada Santista}

Mas [José Roberto Correia] Serra adianta que menos de $60 \%$ dos 7,8 milhões de metros quadrados a serem agregados poderão ser utilizados na atividade portuária em razão de limitações ambientais - a vegetação de Barnabé Bagres é de mangue. De toda forma, pondera que as restrições não podem ser totais. "Ninguém vai me convencer que uma área tem uma classificação ambiental de um lado (margem direita) [do Porto de Santos] e outra completamente diferente do outro (margem esquerda). (Valor Econômico, 2010a; grifos nossos)

Ainda que o então presidente da Codesp não estivesse convencido sobre as diferentes classificações das margens do Porto, a lei complementar n. 359, de 1999 (Santos, 1999), que dispunha sobre as diretrizes de uso e ocupação do solo da fração continental do município de Santos, vigente naquele momento, de fato inviabilizaria a expansão da atividade portuária, uma vez que as áreas situadas ao fundo do estuário de Santos, às margens do canal Piaçaguera, estavam, prioritariamente, gravadas como zona de preservação.

Em 2010, a prefeitura de Santos encaminhou projeto de lei de revisão do Plano Diretor e da Lei de Uso e Ocupação do Solo (Luos) à Câmara Municipal. No texto original, o zoneamento proposto pelo Executivo eliminou substancialmente as zonas de preservação da fração continental, permitindo a expansão da ocupação portuária em Área de Preservação Permanente (APP), junto ao estuário de Santos.

Conforme destacado por Carriço (2012b), a respeito do processo de discussão e votação do Plano Diretor e da Lei de Uso e Ocupação do Solo na Câmara Municipal de Santos, diversas emendas apresentadas ao texto original buscavam transformar o Plano em um instrumento de maior efetividade e aplicabilidade, bem como garantir um padrão menos segregacionista e mais sustentável ao processo de urbanização e ocupação do território do município. Um exemplo é, segundo 
Carriço (ibid.), "[...] a emenda, inspirada em manifestação do Ibama, que impossibilitaria a ampliação de áreas destinadas a porto e retroporto, na área continental". Essa emenda, no entanto, foi rejeitada, comprometendo, na visão do urbanista, "o destino de milhões de metros quadrados de manguezais" (ibid.).

Ao final da votação, parte significativa das áreas situadas ao fundo do estuário, e que abrange os bairros de Piaçaguera, Bagres, Nossa Senhora das Neves e Barnabé, localizados entre as margens do canal e a Rodovia Cônego Domenico Rangoni, foi transformada em área de expansão urbana e gravada como Zona Portuária e Retroportuária.

Não há como negar que o novo zoneamento incorporado à Luos de 2011 convergia com as diretrizes do Zoneamento Ecológico-Econômico (ZEE) da Baixada Santista, ${ }^{21}$ sistematizadas e divulgadas em 2008 como produto de um longo processo de trabalho, desenvolvido pelo Grupo Setorial de Coordenação da Baixada Santista, sob a responsabilidade da Coordenadoria de Planejamento Ambiental da Secretaria do Meio Ambiente do estado de São Paulo e que contou com a participação de representantes do governo do estado, dos municípios e da sociedade civil. 22

Segundo Botelho (2003), "o Zoneamento Ecológico-Econômico pode ser entendido como um instrumento de planejamento ambiental, cujo objetivo fundamental é subsidiar as decisões de uso e ocupação do território em bases sustentáveis, por meio da análise integrada de fatores físicos, bióticos e socioeconômicos" (Botelho, 2003 apud SMA, 2013 , p. 30). Contribuindo com essa leitura, Steinberger (2006) esclarece, que o ZEE é, fundamentalmente, um instrumento de gestão ambiental e territorial concebido para integrar e espacializar políticas públicas, ordenar o território, e que, no seu arranjo político-institucional, previu-se a participação de vários agentes sociais por meio de atores locais, regionais, nacionais e internacionais. $E$, ainda segundo a autora, "O fato dessa concepção muitas vezes ter sido desvirtuada não significa que o ZEE não possua esses potenciais" (Steinberger, 2006, p. 171).

Em 2008, o projeto do ZEE da Baixada Santista, quando enviado para apreciação do Conselho Estadual de Meio Ambiente (Cosema), já previa o crescimento da atividade portuária em fração significativa dessa região.

Considerando que sua abrangência ultrapassa os limites político-administrativos municipais e circunscreve territórios rurais, urbanos e ambientalmente sensíveis, deveria ser observada uma relação de complementaridade entre o zoneamento urbano e o ZEE, uma vez que o primeiro pode ser subsídio para o segundo e vice-versa. De fato, tal complementaridade foi considerada tanto pela revisão da Lei de Uso e Ocupação do Solo municipal de 2011, quanto pelo decreto estadual n. 58.996, de 25 de março de 2013, que, por fim, ratificou o ZEE da Baixada Santista e incorporou os mesmos limites definidos pelo zoneamento municipal, ao estabelecer, para a referida região, a Zona 5 Terrestre de Expansão Portuária $\left(\right.$ Z5TEP) ${ }^{23}$ e a Zona 5 Marinha de Expansão Portuária (Z5MEP). ${ }^{24}$

Estas são áreas ainda não ocupadas ou parcialmente ocupadas, com cobertura vegetal caracterizada como mangue em sua maior parte. $E$, embora tenham sofrido alterações provocadas pela degradação ambiental do estuário, ainda apresentam condições de sustentar os principais fluxos ecológicos associados ao ecossistema da região. Mesmo 
com esses atributos ambientais, o relatório da SMA (2013) sugeriu que tais áreas, em função de suas peculiaridades geográficas e socioeconômicas, fossem consideradas de interesse estratégico para o desenvolvimento e expansão portuária e retroportuária e, também, para ampliação da infraestrutura ferroviária e rodoviária.

Como visto, aspectos econômicos prevaleceram sobre os elementos físicos e bióticos da região, pois, a despeito da legislação ambiental em vigor, que protege manguezais, restingas e a Mata Atlântica, foram criadas, tanto pelo ZEE da Baixada Santista (2013), quanto pela Lei de Uso e Ocupação do Solo de Santos (2011), as condições imprescindíveis para que as fronteiras da atividade portuária avançassem pelo território na direção do canal Piaçaguera. Diante do ocorrido, é impossível discordar da afirmação de Steinberger que supõe "[...] o ZEE, como síntese de informações, conflitos e decisões, deve ser a expressão espacial de uma rede de relações de poder dos agentes e seus respectivos atores" (2006, p. 163). Não só o ZEE como também planos diretores e leis de zoneamento, enquanto instrumentos de gestão urbana, são expressão de uma rede de relações de poder, uma vez que incidem sobre o espaço urbano, que, segundo a autora, "é aglutinador de relações de poder" (ibid., p. 152).

Como visto, tanto a Luos de Santos (2011), quanto o ZEE da Baixada Santista (2013) são, de fato, a expressão espacial não de uma relação justa e equilibrada de poderes que disputam ideias e projetos para o território, mas de uma relação desigual entre as forças dos diversos agentes que usam e disputam o território, assim como é desigual a voz - política - que os representa.
Sob a nova perspectiva dos greenfields projects, em outubro de 2011, a imprensa noticia que a empresa São Paulo Empreendimentos Portuários (SPEP) realizaria investimento de cerca de $\mathrm{R} \$ 2$ bilhões para implantação de complexo formado por estaleiro de reparos navais e terminais multiuso no Porto de Santos, especificamente, na llha de Bagres (A Tribuna, 2011). Apesar de o processo tramitar, desde 2009, junto ao Instituto Brasileiro de Meio Ambiente e Recursos Naturais Renováveis (Ibama), o projeto tornou-se público naquela data, no momento da realização da audiência pública para tratar do empreendimento, em cumprimento aos ritos processuais de licenciamento ambiental, após um mês da entrega do Estudo e Relatório de Impacto Ambiental (EIA-Rima) pela SPEP ao órgão ambiental.

0 assunto logo ganhou repercussão $0^{25}$ na sociedade, suscitando diversos questionamentos, relacionados, entre outros aspectos, à questão fundiária. Como seria possível o trâmite do licenciamento ambiental do empreendimento privado, uma vez que sobre a área já havia pleito da Codesp junto aos órgãos portuários? Uma vez que, desde 2008, tramitava entre a Antaq e a Secretaria Especial de Portos solicitação da Codesp para alterações dos limites do Porto Organizado de Santos, estabelecido pelo decreto n. 4.333 , de 2002, visando a incorporar a área da Ilha de Bagres para construção do terminal público, denominado Projeto Barnabé-Bagres.

A empresa afirmou ter adquirido, da Secretaria do Patrimônio da União (SPU), o domínio útil no valor de cerca de $\mathrm{R} \$ 15$ milhões $(A$ Tribuna, 2011). Mas como seria possível uma empresa privada obter aforamento ${ }^{26}$ oneroso de terreno da União, sem que ninguém tivesse tomado conhecimento dos procedimentos do 
leilão ou da concorrência pública para disponibilização da área de domínio da administração federal para uma empresa de capital privado?

Em entrevista publicada no jornal $A$ Tribuna, em 6 de dezembro de 2011, o diretor presidente da Codesp, José Roberto Correia Serra, demonstrou descontentamento sobre a falta de agilidade da Antaq e da Secretaria Especial de Portos da Presidência da República (SEP/PR) a respeito das definições em torno da ampliação dos limites do Porto de Santos (Carriço, 2011). Além do projeto recém-divulgado, pretendido pela empresa SPEP para a Ilha de Bagres, veio à tona a informação de que outro empreendimento, conhecido como Terminal Brites, do Grupo Triunfo, também estaria em fase de licenciamento ambiental, ${ }^{27}$ e que este se sobrepunha, assim com o Complexo Bagres, à área compreendida pelo projeto Barnabé-Bagres, almejada pela Codesp há mais de uma década.

Considerando a sobreposição de interesses pela referida área da União, caberia supor não haver espaço de diálogo entre órgãos do governo federal (como Codesp, Secretaria de Portos, Antaq e SPU), em que fosse possível debater a expansão portuária de Santos, território estratégico para a economia e o desenvolvimento nacional. A Codesp, em meio a esse processo, teria feito alguma solicitação formal à SPU manifestando interesse sobre as terras onde o projeto Barnabé-Bagres poderia vir a ser implantado? Quais as razões para que a SEP/PR e a Antaq, desde 2008 e até então, não tenham se pronunciado, de forma conclusiva, ${ }^{28}$ sobre o pedido de expansão dos limites do Porto Organizado de Santos, sob jurisdição da Codesp, para garantir a ampliação do porto público? Ao mesmo tempo, o que justificaria o desapego, sem maiores esclarecimentos, por parte da Codesp, em relação ao projeto que vinha sendo planejado desde o final da década de 1990, a despeito da grande evidência que este ganhou nos últimos anos e do interesse e envolvimento, não só do governo federal, mas de outros setores privados e da prefeitura de Santos, em viabilizá-lo?

\section{A concessão da llha de Bagres: do catador de caranguejo à empresa portuária}

A Ilha de Bagres, com 1.086.421,59 $\mathrm{m}^{2}$ de área, situada no estuário defronte às regiões de Alemoa e Saboó, no município de Santos, é caracterizada como ilha costeira e, portanto, é propriedade da União por força constitucional (art. 20, IV) (Brasil, 1988).

Para garantir o domínio da terra pública federal, agentes privados fizeram uso da seguinte estratégia: uma pessoa física - engenheiro agrimensor responsável pelos levantamentos técnicos iniciais da ilha, que tinha adquirido, a preço de "banana", os direitos possessórios da área de pequenos sitiantes, pescadores e catadores de caranguejo, que tradicionalmente ocupavam tais áreas para subsistência - formalizou por "instrumento particular e cessão de posse e aquisição de benfeitorias", pedido de regularização da situação através da inscrição de ocupação (IO), justificada pelo exercício do efetivo aproveitamento da área por atividades permitidas em território, então caracterizado como Área de Preservação Ambiental.

Cabe recuperar que a inscrição de ocupação (IO) é um ato administrativo precário, resolúvel - de atribuição exclusiva da SPU -, e pressupõe o efetivo aproveitamento do terreno 
pelo ocupante, sendo este o requisito para o reconhecimento do direito de uso das terras públicas da União. As formas de verificação do efetivo aproveitamento de um determinado imóvel são estabelecidas por norma jurídica ${ }^{29}$ e passam pela proporcionalidade entre a área construída, o tempo de ocupação, as benfeitorias nela existentes e a finalidade de uso. A efetivação do cadastramento do ocupante no sistema gerencial da SPU, mediante análise de conveniência e oportunidade, com o propósito de regularizar uma situação fática, pode ser realizada por iniciativa da SPU ou a pedido do próprio interessado, como no caso em questão. Tal ato gera, automaticamente, obrigações do ocupante para com a União, por meio do pagamento anual de taxa de ocupação como contraprestação pelo uso do imóvel público por um particular.

A comprovação da cadeia sucessória também é elemento fundamental tanto para justificar a inscrição de um ocupante, quanto para que a SPU possa realizar a cobrança dos débitos devidos. Vale observar, ainda, que na época do pleito em análise somente as ocupações ocorridas até 1997 poderiam ser reconhecidas pela União. ${ }^{30}$ Além desses aspectos, para melhor compreensão do caso, é necessário esclarecer que a inscrição de ocupação, como instrumento de reconhecimento de posse, é o fundamento jurídico do direito de preferência ao aforamento, ${ }^{31}$ desde que o ocupante esteja em dia com a União.

Voltando ao caso, uma vez deferida a IO pela União em nome do particular, as cessões de posse foram transferidas para empresa portuária (constituída por sociedade de pessoa jurídica, majoritariamente de capital estrangeiro) e formalizadas junto à União, ainda que não fosse permitido, na ocasião, qualquer tipo de atividade correlata nessas áreas. Diante da regularização da ocupação em nome da empresa, que lhes garantiu o direito de preferência para constituir o regime enfitêutico (previsto em lei), a empresa requisitou a aquisição do aforamento oneroso, que foi concedido pela superintendência do patrimônio da União diante de uma avaliação subdimensionada, realizado por procedimento simples, não carecendo de qualquer análise jurídica ou de homologação superior. Contornando, dessa maneira, os trâmites licitatórios exigidos por lei, mas, também, o debate mais amplo sobre o destino daquele território e o controle sobre o que, por quem e como poderia ser viabilizado.

Apesar do interesse público sobre a área e do amplo conhecimento das pretensões sobre o antigo projeto Barnabé-Bagres, os órgãos competentes e responsáveis pelo assunto de portos (como a então Secretaria Especial de Portos ligada à presidência, a Antaq e Codesp), em nenhum momento tomaram qualquer medida administrativa efetiva para garantir o acesso à terra da União. Além disso, ainda que fosse o órgão responsável pela gestão dos bens da União, caberia à SPU arbitrar sobre o destino de um bem público, interferindo ou contrariando as diretrizes da política de portos? Em nosso entendimento, de maneira alguma, principalmente, se observado o fato de o canal de Santos ser um território considerado de interesse nacional e estratégico para atividade portuária. Diante disso, ainda que a Antaq não tivesse manifestado objeções, seria razoável supor que qualquer decisão sobre um território de tal natureza demandaria, no mínimo, um debate interno ao governo, ao menos com a Casa Civil e demais interlocutores responsáveis pelas questões de portos. Até mesmo para que a SPU pudesse se valer do 
argumento de que não estaria na esfera de sua competência o controle sobre a finalidade pela qual um imóvel é, ou será, utilizado. Isso estaria justamente em consonância com a Política Nacional de Gestão do Patrimônio da União daquele momento, que estabelecia que a gestão das terras da União tinha como propósito atender aos interesses da nação, em apoio às políticas públicas federais, visando à garantia de direitos fundamentais e ao desenvolvimento econômico e social do País.

Outro aspecto a ser observado diz respeito à teia de interação entre esses agentes privados que não só se restringia à relação interpessoal circunscrita ao próprio grupo de empresas, mas também se embrenhou na complexa, fragmentada e heterogênea estrutura do Estado, na qual transitou internamente em meio aos diferentes órgãos e instituições públicas, nos diversos níveis de governo, a partir de distintas, e indistintas, formas de interlocução.

Para dar fim às restrições de uso do território fora do alcance do mercado, foi preciso torná-lo "utilizável" e potencialmente apto a ser explorado pelos grupos econômicos interessados na região. No município de Santos, durante o processo de revisão do Plano Diretor e da Lei de Uso e Ocupação do Solo, os setores locais de pequenos portuários com capacidade de utilização das áreas do porto público consolidado e que possuem uma interface com a cidade, não só participaram das arenas de negociação junto ao poder Executivo, como demonstraram ter grande representatividade e poder de barganha nesses espaços. ${ }^{32} \mathrm{E}$, assim como outros setores que compõem o ConseIho Municipal de Desenvolvimento Urbano de Santos, esses setores portuários locais entraram no debate de ideias para disputar e definir quais áreas atenderiam aos seus interesses. Diferentemente, o grande capital internacional interessado e com capacidade financeira para viabilizar os greenfields projects nas margens do canal Piaçaguera - garantiu a negociação "por cima", em função do trânsito político que possui e de relações de pessoalidade, sem passar necessariamente pelas arenas de decisão local, apesar do impacto gerado no território do município.

A suposição de que os representantes da empresa SPEP circulavam entre os meandros institucionais de governo (nas três esferas) está baseada, também, no fato de a empresa ter garantido o acesso às terras da União sem prescindir da concorrência pública, ao se valer de subterfúgio normativo e seus efeitos (o direito de preferência ao aforamento em decorrência do regime de ocupação), algo tão particular da legislação patrimonial dos imóveis da União. Trata-se do mesmo acesso privilegiado que a SPEP demonstrou possuir junto às estruturas institucionais do governo do estado de São Paulo, quando buscou obter, por meio da Secretaria Estadual de Desenvolvimento Econômico, a declaração de utilidade pública da área, documento de importância estratégica para a concretização do empreendimento portuário. ${ }^{33}$

A SPEP, todavia, não seria a única empresa interessada nesse novo flanco de realização de capital. Outros agentes privados já estavam se movimentando para garantir sua fatia dentro desse território. Uma série de fragilidades (aparentemente planejadas), a existência de pessoalidade das relações entre agentes privados e públicos e o acesso privilegiado a informações por um grupo bem postado junto ao Estado reforçaram a ideia de que, de fato, existia uma atuação coordenada 
para atender aos interesses de determinado grupo, na execução de grandes investimentos na região.

Diante da série de denúncias que envolveram o setor portuário, após deflagrada a Operação Porto Seguro (2012) da polícia federal e da constatação de vícios processuais contrários ao interesse público, ${ }^{34}$ foi proposto o cancelamento dos aforamentos por nulidade das inscrições de ocupação incidentes sobre a área da Ilha de Bagres, deferidas anteriormente a favor da empresa São Paulo Empreendimentos Portuários, sendo, assim, iniciados os processos de reintegração de posse das áreas pela SPU. Junto disso, foi anunciado pelo governo em dezembro, do mesmo ano, novo modelo de gestão dos portos, que pretendia trazer mais transparência para o setor.

Em relação às alterações propostas pela medida provisória n. 595, de 2012, convertida na Lei de Portos de 2013 (lei federal n. 12.815), entre outras medidas, ${ }^{35}$ ganhou destaque o fim da diferenciação entre as operações de cargas próprias e de terceiros nos terminais privativos, prevista no decreto n. 6.620 de 2008. Por fim, vale destacar que, após a Operação Porto Seguro, nenhuma outra inscrição de ocupação na região do estuário de Santos foi cadastrada pela SPU-SP, ao menos até $2016 .{ }^{36}$ As áreas da Ilha de Bagres, Sítio do Caneu e Sítio Boa Vista, objetos das concessões de aforamentos anuladas, foram declaradas como de interesse público para utilização da atividade portuária pela portaria SPU n. 327, de 19 de dezembro de 2014, na qual ficou estabelecido que uma futura destinação seria definida por ato conjunto entre SPU e SEP/PR, numa tentativa de gestão mais transparente e coordenada entre os órgãos gestores da terra pública e do setor portuário.

\section{Considerações finais}

O Porto de Santos, desde sua constituição originária na virada do século XIX para XX, não parou de se expandir, atravessando todos os ciclos econômicos do País (do café, da indústria, dos contêineres), manipulando diversos tipos de cargas e adotando novas soluções tecnológicas, sem, no entanto, resolver sua relação com a cidade. $O$ centro das decisões sobre as transformações da atividade portuária propostas em Santos esteve distante da realidade urbana impactada, mas não necessariamente alheio às diretrizes da política urbana e de zoneamentos locais - e daquilo que precisaria ser alterado para viabilizar os empreendimentos portuários pretendidos.

A despeito do desenvolvimento local e urbanístico que veio a reboque do desenvolvimento do Porto de Santos, no contexto do social-desenvolvimentismo - o modelo de desenvolvimento consolidado nas duas primeiras décadas do século XXI (Nobre, 2013) -, os ganhos de capital, mais uma vez, prevaleceram sobre os interesses locais. Santos sempre foi uma cidade que tem um porto, e não necessariamente uma cidade portuária, ainda que a cidade viva e dependa economicamente desse setor, em que cerca de $60 \%$ do PIB municipal tem origem na atividade portuária ou em atividades que lhes são complementares. O Porto, de fato, gera desenvolvimento para a cidade de Santos, mas, também, impacto sobre o espaço urbano, decorrente de negociações e de contínuos ajustes traumáticos impostos por cada novo ciclo econômico.

A formação e a evolução do Porto de Santos também mostraram como se deu, e como ainda se perpetua, a inserção periférica 
do Brasil dentro do sistema de acumulação global, com o principal propósito de estabelecer um eficiente processo de exportação de commodities, ainda que, em meados do século $X X$, o processo de industrialização paulista, e não a exportação de produtos primários, tenha dado a tônica da reestruturação portuária ocorrida naquele período.

Diante do processo observado, no momento da história do capitalismo em que há predomínio da lógica financeira, estão presentes e de maneira enfática, mais do que em outros momentos, processos típicos da fase de acumulação primitiva do capital (Harvey, 2005) "marcados por um estreitamento das relações entre poder e dinheiro, uma vez que o sistema é marcado pela discricionariedade, pelo compadrio e pelo privilégio" (Paulani, 2010). Fraudes, roubos, usurpações e outras práticas imorais nunca deixaram de existir completamente, mas vêm se mostrando, segundo Paulani (ibid.) de forma mais exacerbada no contexto em que ocorreram crises de sobreacumulação experimentadas das últimas décadas.

0 rentismo, característico desse momento, procura extrair o máximo retorno financeiro, no menor prazo de tempo possível, e só se arrisca em situações em que haja perspectiva de enormes ganhos. Assim, nas circunstâncias que envolvia uma significativa quantidade de capital excedente disponível no sistema de acumulação financeira mundial, agentes privados, no caso da Ilha de Bagres, buscaram através do trânsito político junto às estruturas públicas, nas brechas do insulamento burocrático, ${ }^{37}$ minimizar os potenciais riscos que poderiam correr diante da operação necessária para empreender terminais portuários de grande monta na região de Santos. Valeram-se, portanto, de distintos mecanismos que, de acordo com Paulani (ibid., p. 130), são capazes de "transformar o jogo capitalista cada vez mais num jogo de cartas marcadas", conforme buscamos debater neste artigo.

É certo, conforme manifestado por Marx (apud Harvey, 2005, p. 47), que, "embora a indústria do transporte seja, potencialmente, uma fonte de mais-valia, há boas razões para que o capital não se engaje em sua produção, exceto sob certas circunstâncias favoráveis. Desse modo, o Estado é, muitas vezes, bastante ativo nessa esfera de produção".

É certo também que tal relação, no mínimo controversa, entre o Estado e o capital não é algo novo na história do Porto de Santos. Basta recuperar o modo pelo qual se deu a concessão do governo Imperial à família Guinle para garantir a construção e a operação do Porto, ainda no século XIX (Moreira, 2018). Entretanto, qual seria a fronteira entre o legal e o legítimo sobre a qual o Estado poderia atuar com o propósito de criar as tais circunstâncias favoráveis, minimizando os riscos dos agentes privados? Especialmente, naquilo que se refere a gestão e apropriação das terras públicas por agentes privados?

No caso em questão, assegurar o domínio da terra pública não apenas como suporte para a construção das novas instalações portuárias, mas como mecanismo de garantia, tanto para ações compensatórias decorrentes do processo de licenciamento ambiental, como para alavancar, de maneira coordenada, financiamentos públicos e privados necessários para o empreendimento pretendido, foi o motivo que justificou a constituição do regime enfitêutico (a concessão do domínio útil à empresa SPEP), em detrimento de outros instrumentos jurídicos. Cumpre questionar, todavia, quais seriam as razões que justificariam, 
por parte da União, o comprometimento de seu próprio bem público como garantia a ela mesma, fosse diante de ações compensatórias, fosse para alavancar financiamentos para viabilizar o empreendimento privado?

A devida exploração econômica dos bens públicos, como antes mencionado, implicaria o atendimento de ao menos um dos três objetivos indicados por Marques Neto:

(1) gerar receitas para o poder público;

(2) atrair os particulares para darem uma determinada utilidade ao bem, utilidade esta que seja de interesse geral; ou (3) fomentar a utilização de um bem público ocioso, de modo a que ele cumpra sua função social correspondente a produzir riquezas para a sociedade. (2014, p. 433)
A partir dos elementos abordados neste artigo, foi possível observar que os princípios que deveriam balizar a equilibrada e eficiente exploração econômica de bens da União passaram ao largo dos processos que envolveram a destinação das terras públicas federais na região de Santos. E o que se viu, diante do descolamento das diretrizes incidentes sobre a gestão do patrimônio da União, foi um mirabolante e embrenhado processo de usurpação de terras públicas por agentes privados, combinado com outras estratégias necessárias para abrir novas fronteiras para realização do capital e para tornar áreas, originalmente gravadas como de preservação ambiental, aptas para receberem novos empreendimentos portuários.

\section{[I] https://orcid.org/0000-0002-0305-777X}

Universidade de São Paulo, Faculdade de Arquitetura e Urbanismo, Laboratório Espaço Público e Direito à Cidade. São Paulo, SP/Brasil.

fefaccioly@gmail.com

\section{Notas}

(1) Termo trazido pelo economista Edmar Bacha e Laura Carvalho (Carvalho, 2018).

(2) Empreendimentos portuários de grandes proporções implantados áreas verdes definidas, originalmente, como áreas de preservação ambiental.

(3) Cf. art. 2, I, da lei federal n. 12.815/2013, considera-se "porto organizado": bem público construído e aparelhado para atender a necessidades de navegação, de movimentação de passageiros ou de movimentação e armazenagem de mercadorias, e cujo tráfego e operações portuárias estejam sob jurisdição de autoridade portuária, no caso do Porto de Santos, a Codesp.

(4) "Manobra de flanco" é expressão utilizada para descrever uma manobra tática militar ofensiva específica, que visa a contornar as alas das posições inimigas, atacando seus flancos/lados ou sua retaguarda. Como toda estratégia, apresenta vantagens e riscos e pode sofrer com o ataque inimigo em defesa dos flancos atacados. 
(5) Na Santos Export de 2003: Fórum Internacional, que reúne empresários, autoridades e especialistas sobre o assunto, criado para promover debate sobre assuntos portuários, com o objetivo de analisar e propor estratégias para o desenvolvimento do complexo marítimo de Santos.

(6) "A participação no valor total desse tipo de produto exportado aumentou da casa dos $25 \%$ entre 1995 e 2002, passando para 29,3\% entre 2003 e 2006, até alcançar o patamar de 36,5\% entre 2007 e 2009, gerando, em contrapartida, reduções na participação dos semimanufaturados e dos manufaturados entre 2003 e 2009" (Pinto, 2013, p. 92).

(7) De acordo com Sanchez (2007), coordenador econômico da Comissão Econômica para a América Latina e o Caribe (Cepal), ligada às Nações Unidas.

(8) “O terminal [BTP] foi construído na área do antigo lixão da Companhia Docas de Santos, que segundo a lenda escondia em seu solo toda a tabela periódica. O processo de descontaminação do solo do local foi alvo de algumas polêmicas durante os processos de licenciamento e construção do empreendimento" (Carriço, 2012a).

(9) “[...] outra obra importante é a ampliação do cais de granéis líquidos com a construção de mais dois berços de atracação. Essa ampliação corresponde a uma demanda em expansão constante, que exige investimentos da iniciativa privada, como foi o caso da Stolthaven, especializada em granéis líquidos" (Gonçalves e Nunes, 2007, p. 268).

(10) A Santos-Brasil venceu o processo de licitação do Tecon Santos em novembro de 1997 e obteve a concessão para prestação de serviços portuários por 25 anos, renováveis por mais 25 (O Estado de S.Paulo, 2008; Dualibi e Pereira, 2008).

(11) Manifestaram interesse em desenvolver projetos para a área de Barnabé-Bagres, além da empresa Santos-Brasil, o Grupo Libra Terminais, que atua no Porto de Santos operando terminais de contêineres na margem direita; a empresa Triunfo, de capital aberto, atuante nos setores portuário, rodoviário, logístico e energético, permissionária para exploração do Porto de Navegantes, em Santa Catarina, e que apresentou projeto polêmico de TUP denominado "Brasil Intermodal Terminal Santos - Brites", no largo de Santa Rita - citado neste trabalho; e, ainda, o consórcio formado pelas empresas Tecondi, Deicmar e Marimex (Revista Portuária, 2008).

(12) Entre tais controvérsias, destacamos: a ação civil pública do Ministério Público Federal sobre a validade da declaração de utilidade pública para fins do licenciamento ambiental e a autorização da supressão da vegetação para instalação do TUP, emitida pela prefeitura de Santos, uma vez que a competência para conferir esse tipo de declaração seria do governo federal. E, ainda, em 2009, a Embraport, em Santos, bem como, o Portonave (SC), e os terminais de Itapoá (SC) e Cotagipe (BA) tornaram-se alvos do TCU, em decorrência de denúncias apresentadas pela Abratec e pela Federação Nacional dos Portuários (FNP), que os acusaram de atuar na movimentação de cargas de terceiros ilegalmente.

(13) Uma vez que o artigo 4, da lei n. 8.630, de 1993, não apresentava especificações e não havia outras regulamentações posteriores sobre o assunto.

(14) Para uma abordagem detalhada das divergentes posições sobre o assunto e os desdobramentos de tal polêmica, ver: Guimarães e Araújo Jr (2011) e Werneck (2008).

(15) O jornal Valor Econômico, ao longo dos anos de 2007 e 2008, pautou essa discussão. Inúmeras reportagens sobre o assunto trouxeram o embate de ideais entre os interessados na resolução do impasse sobre as diferentes inserções de distintos grupos privados no setor portuário em crescimento. 
(16) Uma vez que, entre as atribuições da União previstas na Constituição Federal de 1988, conforme artigo 21, XII, f, está a de: “XII - explorar diretamente ou mediante autorização, concessão ou permissão: [...] f) os portos marítimos, fluviais e lacustres" (Brasil, 1988).

(17) Vale lembrar, por exemplo, que o Grupo Opportunity, do banqueiro Daniel Dantas, alvo da operação Satiagraha, da Polícia Federal, é um dos sócios da empresa Santos-Brasil, arrendatária do Terminal de Contêineres (Tecon Santos) e do Terminal de Exportação de Veículos (TEV). E o Grupo Libra, arrendatário de Terminais de Contêineres dos terminais 35 e 37, é ligado ao político Michel Temer.

(18) Nas disposições trazidas pelo decreto lei n. 5, de 1966, e na resolução da Antaq n. 517, de 2005.

(19) Companhia Docas do Rio de Janeiro (CDRJ); Companhia Docas do Estado da Bahia (Codeba); Companhia Docas do Ceará (CDC); Companhia Docas do Estado de São Paulo (Codesp); Companhia Docas do Pará (CDP); Companhia Docas do Maranhão (Codomar); Companhia Docas do Rio Grande do Norte (Codern); e Companhia Docas do Espírito Santo (Codesa).

(20) Segundo o Dicionário Básico Portuário (Governo do Estado do Paraná, 2011, p. 20), berço são "locais de atracação e de movimentação das cargas a serem embarcadas e descarregadas".

(21) O ZEE está previsto no Plano Estadual de Gerenciamento Costeiro, instituído pela lei estadual n. 10.019/1998, com a finalidade de promover a conservação dos ecossistemas costeiros e a melhoria da qualidade ambiental na Zona Costeira, a qual foi elevada à categoria de Patrimônio Nacional, pela Constituição Federal de 1988.

(22) "O Grupo Setorial de Coordenação da Baixada Santista trabalhou desde 2003, em sucessivos mandatos, na construção de uma proposta de zoneamento para a região. Porém, apenas em fevereiro de 2009, logrou concluir uma proposta em condições de ser enviada à análise do Cosema que, todavia, destacou uma série de aspectos relacionados ao mapa e ao texto de decreto que deveriam ser readequados" (SMA, 2013).

(23) “[...] tem localização estratégica por suas peculiaridades geográficas e socioeconômicas e é uma zona na qual são permitidos, além dos usos estabelecidos para Z1T, mineração e empreendimentos portuários e retroportuários, observadas e respeitadas as legislações pertinentes" (SMA, 2013, p. 40).

(24) “[...] tem localização estratégica por suas peculiaridades geográficas e socioeconômicas e é uma zona na qual são permitidos, além dos usos estabelecidos para Z1M, empreendimentos portuários e retroportuários, desde que atendida a legislação pertinente, e pesca artesanal, sendo vedado o arrasto motorizado" (SMA, 2013, p. 42).

(25) Ver post do professor José Marques Carriço no blog Olhar Praiano: <http://olharpraiano.blogspot. com.br/>. Ver também reportagens publicadas em jornais locais, como A Tribuna. A repercussão também se deu em função da audiência pública realizada no dia 26 de outubro de 2011 sobre o empreendimento Centro Portuário Industrial Naval Offshore de Santos - Complexo Bagres, na etapa do processo de licenciamento ambiental, e pela Câmara Temática de Planejamento e Pesquisa da APA Marinha Litoral Centro, diante da divulgação do empreendimento.

(26) Aforamento é um instituto jurídico pelo qual a União transfere, de forma onerosa ou gratuita, o domínio útil de seus bens ( $83 \%$ do domínio do terreno), mediante processo licitatório. Tal instrumento, na teoria, deveria ser utilizado pelo governo federal em situações em que há interesse em manter o imóvel sob seu domínio, uma vez que o domínio direto 17\% do imóvel permanece com a União, e, por isso, é utilizado prioritariamente em terrenos de marinha, acrescidos de marinha e terrenos marginais, cujo domínio pleno é intransferível. 
(27) Em matéria publicada no portal G1, Eduardo Carvalho relata: "Chamado de 'Terminal Brites', o porto privado vai ser operado pela empresa Vetria Mineração - um consórcio operado pela América Latina Logística (ALL), a Triunfo Participações e Investimentos e a Vetorial Mineração. A empresa será responsável pela extração, transporte e comercialização de minério de ferro proveniente do Maciço do Urucum, em Corumbá (MS)". Segundo a matéria, o terminal seria instalado na margem esquerda do Porto de Santos, situado no largo de Santa Rita. O Ibama havia concedido a licença prévia em abril de 2011, e a empresa aguardava a licença de instalação, quando o Ministério Público Federal apresentou ação civil pública para impedir a sua construção, motivado pelo fato de a região ser "um dos maiores complexos de mangue do Sudeste do Brasil. É uma área de águas rasas e bancos de sedimentos, com grandes bancos de mexilhões, algas e uma fauna rica de crustáceos e pequenos peixes que servem de alimento para aves que habitam a região [...], ao menos 20 espécies de aves consideradas ameaçadas de extinção, como o guará-vermelho (Eudocimus ruber)" (Carvalho, 2012).

(28) De acordo com matéria de Pires (2012), em junho de 2011, depois de idas e vindas a respeito de correções feitas no perímetro do porto organizado de Santos, finalmente a Antaq aprovou a expansão do porto público e, em 8 de julho, enviou o processo para a SEP/PR, onde permanece sem novos elementos.

(29) Até 2014, a inscrição de ocupação era regulamentada pelas portarias da SPU n. 583, de 1992, e n. 7, de 2001. Naquele ano, foi editada a portaria SPU n. 259, que alterou algumas disposições para aplicação da inscrição de ocupação, visando a estabelecer maior controle, pelo órgão central, dos procedimentos realizados pelas superintendências. Conforme informações concedidas por ex-gestores da SPU, por meio de entrevista, a adoção de procedimentos mais rigorosos foi motivada após serem deflagradas operações da Polícia Federal, como Operação Porto Seguro (SP), Operação Perímetro (DF) e Operação Vista Mar (BA) - a respeito de irregularidades na destinação de terrenos da União a particulares.

(30) Lei federal n. 9.636, de 1998, artigo 9으, inciso I.

(31) Artigo 13 da lei federal n. 9.636, de 1998.

(32) A exemplo da tradicional Associação de Comerciários de Santos (ACS), de grande prestígio e representatividade local, que foi anfitriã de diversas audiências públicas ao longo do processo de revisão do Plano Diretor e da Luos de Santos.

(33) Bruno Boghossian e Julia Duailibi relatam o caso, em reportagem do jornal O Estado de S.Paulo, publicada em 11 de janeiro de 2013: “Em 6 de janeiro de 2012, a empresa São Paulo Empreendimentos Portuários, que a PF diz pertencer a Miranda, enviou à secretaria um pedido de reconhecimento de utilidade pública. A pasta deu encaminhamento ao projeto e, posteriormente, declarou que era 'imprescindível para a expansão portuária paulista'. [...] O prefeito [ex-secretário estadual de desenvolvimento econômico de São Paulo] destacou ainda que Miranda procurou a secretaria para obter a declaração de utilidade pública da ilha com objetivo de obter licenciamento ambiental, que o pedido foi encaminhado à Procuradoria do Estado, que emitiu parecer contrário, por considerar impertinente a declaração nos termos da solicitação" (Boghossian e Duailibi, 2013).

(34) Com base no parecer n. 3875-5.12/2012/MAA/Conjur-MP/CGU/AGU, que considerou a nulidade do despacho emitido pelo adjunto da $A G U$, pela ausência de competência para proferir orientação jurídica, que acabou contaminando os atos administrativos praticados em sua observância. A SPU publicou a portaria n. 353, de 30/11/2012, sobrestando os efeitos dos despachos concessórios dos respectivos aforamentos. 
(35) Para os arrendamentos de terminais em berços públicos, ficou estabelecido o prazo de 25 anos, renováveis uma única vez, para redefinição dos critérios de licitação a partir da maior movimentação com menor tarifa, e a padronização e centralização das licitações, realizadas por leilão, pela Antaq. Em relação aos TUPs, as autorizações para sua instalação seriam precedidas de chamada pública realizada pela Antaq, e o prazo seria de 25 anos, com renovações sucessivas.

(36) Informação fornecida por coordenador da área de caracterização da SPU-SP, em entrevista realizada em 16 de junho de 2016.

(37) Sobre o insulamento burocrático Edson Nunes (2003) afirma: "O insulamento burocrático é percebido como uma estratégia para contornar o clientelismo através da criação de ilhas de racionalidade e de especialização técnica. Na linguagem da teoria organizacional contemporânea, o insulamento burocrático é o processo de proteção do núcleo técnico do Estado contra a interferência oriunda do público ou de outras organizações intermediárias" (Nunes, 2003, p. 34).

\section{Referências}

AGÊNCIA SENADO (2013). Criação brasileira, definição de "terrenos de marinha" vem de séculos. Senado Federal. 4 abr. Disponível em: <https://www12.senado.leg.br/noticias/materias/2013/04/04/ criacao-brasileira-definicao-de-2018terrenos-de-marinha2019-vem-de-seculos>. Acesso em: 26 set 2016.

ARAÚJO, T. B. (2013). "Tendências do desenvolvimento regional recente no Brasil”. In: BRANDÃO, C.; e SIQUEIRA, H. Pacto federativo, integração nacional e desenvolvimento regional. São Paulo, Editora Fundação Perseu Abramo.

ARAÚJO JR., J. T.; GUIMARÃES, E. A. (2010). Regulação e desempenho dos portos brasileiros. Revista Brasileira de Comércio Exterior, n.107, v. 25, Disponível em: <http://www.funcex.org.br/ publicacoes/rbce/material/rbce/107_eagjta.pdf>. Acesso em: 28 out 2017.

ARRETCHE, M. (2012). Democracia, federalismo e centralização no Brasil. Rio de Janeiro, Fundação Getúlio Vargas/Fiocruz.

A TRIBUNA (2011). Bagres terá complexo de R\$ 2 bi. A Tribuna, 11 out. Disponível em:<https://www. portosenavios.com.br/noticias/ind-naval-e-offshore/11392-bagres-tera-complexo-de-r-2-bi>. Acesso em: 15 jun 2016.

(2016). SPU terá que explicar reajuste de taxa em área de marinha. A Tribuna, 23 maio. Disponível em: <http://www.atribuna.com.br/noticias/noticias-detalhe/cidades/spu-tera-queexplicar-reajuste-de-taxa-em-area-de-marinha/?cHash=04a975ac3a9488c4ed292b946f20aa fd>. Acesso em: 28 nov 2016.

BOGHOSSIAN, B.; DUAILIBI, J. (2013). Tucano ajudou acusado da Operação Porto Seguro. O Estado de S.Paulo, 11 jan. Disponível em: <http://politica.estadao.com.br/noticias/eleicoes,tucano-ajudouacusado-da-operacao-porto-seguro-imp-,982981>. Acesso em: 17 mar 2017.

BONDUKI, N. (1998). Origens da habitação social no Brasil. São Paulo, FAU-USP. 
BOTELHO, R. G. M. (2003). “Contribuição teórico-metodológica aos estudos de planejamento ambiental". In: BRASIL, Ministério do Meio Ambiente (MMA). Diretrizes Metodológicas e Artigos Selecionados. Brasília, MMA.

BRASIL (1988). Constituição da República Federativa do Brasil de 1988. Disponível em: http://www. planalto.gov.br/ccivil_03/constituicao/constituicao.htm. Acesso em: 8 set 2016.

(2008). ADPF n. 139, de 2 de abril de 2008. Disponível em: <http://www.stf.jus.br/portal/ peticaolnicial/pesquisarPeticaolnicial.asp>. Acesso em: 21 out 2017.

BRENNER, N. (2013). Reestruturação, reescalonamento e a questão urbana. GEOUSP. Espaço e Tempo (on-line), v. 17, n. 1, pp. 198-220. Disponível em: https://doi.org/10.11606/issn.2179-0892. geousp.2013.74311. Acesso em: 10 nov 2019.

BULCÃO, C. (2015). Os Guinle. A história de uma dinastia. Rio de Janeiro, Intrínseca.

CARLINI, N. (2008). Abertura ou fechamento dos portos? Valor Econômico. 28 maio. Disponível em: <https://www.pressreader.com/brazil/valor-econ\%C3\%B4mico/20080528/281805689673423>. Acesso em: 31 jul 2017.

CARRIÇO, J. M. (2009). Foi tudo planejado (parte VIII). Blog Olhar praiano, 19 nov. Disponível em: <http://olharpraiano.blogspot.com.br/search?q=Foi+tudo+planejado>. Acesso em: 23 mar 2017.

(2011). A pulga subiu no telhado. Blog Olhar Praiano. 6 nov. Disponível em: <http://olharpraiano. blogspot.com/2011/12/pulga-subiu-no-telhado.html>. Acesso em: 23 mar 2017.

(2012a). BTP: quase pronto, mas e os acessos? Blog Olhar Praiano. 22 nov. Disponível em: <http://olharpraiano.blogspot.com.br/2012/11/btp-quase-pronto-mas-e-os-acessos.html>. Acesso em: 23 mar 2017.

(2012b). Um balanço da revisão do Plano Diretor de Santos. Blog Olhar Praiano. 7 dez. Disponível em: <http://olharpraiano.blogspot.com.br/search?q=uso+e+ocupa\%C3\%A7\%C3\%A3 o+do+solo>. Acesso em: 23 fev 2017.

CARVALHO, E. (2012). Justiça quer impedir construção de porto de R\$ 1,5 bilhão em Santos, SP. G1. 15 fev. Disponível em: <http://g1.globo.com/natureza/noticia/2012/02/justica-quer-impedirconstrucao-de-porto-de-r-15-bilhao-em-santos-sp.html>. Acesso em: 21 ago 2017.

CARVALHO, L. (2018). Valsa brasileira: do boom ao caos econômico. São Paulo, Todavia.

CARVALHO, M.; CREDENDIO, J. E.; FERREIRA, F. (2012). Advogado de Gilberto Miranda ganhou cargo na agência dos portos. Folha de S.Paulo, 20 dez. Disponível em: <http://www1.folha.uol.com.br/ poder/2012/12/1204208-advogado-de-gilberto-miranda-ganhou-cargo-na-agencia-dos-portos. shtml>. Acesso em: 24 ago 2017.

CENTRO DE PESQUISAS INTERCORP (2012). Complexo Bagres é alvo da Operação Porto Seguro. Intercorp Consultores, $4 \mathrm{dez}$. Disponível em: <http://www.intercorpconsultores.com.br/ noticias/11-noticias/379-complexo-bagres-e-alvo-da-operacao-porto-seguro-.html>. Acesso em: 24 ago 2017.

CODESP (1997). Plano de desenvolvimento e zoneamento do Porto de Santos (PDZPS). Santos, Codesp.

(2016). Análise dos movimentos físicos do Porto de Santos. Santos, Codesp, dez. Disponível em: <http://189.50.187.200/docpublico/amf_cpt/2016/amf-2016-12.pdf>. Acesso em: 5 nov 2017.

DI BELLA, J. (2008). Entrevista. Trade \& Transport, maio. 
DUAILIBI, J.; PEREIRA, R. (2008). Dilma põe petista réu por dispensa de licitação na secretaria dos portos. Estadão, 25 jun. Disponível em: <https://politica.estadao.com.br/noticias/geral,dilma-poe-petistareu-por-dispensa-de-licitacao-na-secretaria-dos-portos,195415>. Acesso em: 27 nov 2017.

EMBRAPORT. "História". Disponível em: <http://www.embraport.com/a-embraport/historia/>. Acesso em: 13 jul 2017.

GONÇALVES, A.; NUNES, L. A. (2007). O grande porto: a modernização do Porto de Santos. Santos, Realejo.

GOVERNO DO ESTADO DO PARANÁ (2011). “Dicionário básico portuário”. Administração dos Portos de Paranaguá e Antonina. Paranaguá. Disponível em: <http://www.portosdoparana.pr.gov.br/ arquivos/File/dicionario2011. pdf>. Acesso em: 17 jan 2018.

GUIMARÃES, E. A.; ARAÚJO JR., J. T. (2011). Regulação e desempenho dos portos brasileiros. Revista Brasileira de Comércio Exterior, v. 25, n. 107. Disponível em: <http://www.funcex.org.br/ publicacoes/rbce/material/rbce/107_eagjta.pdf>. Acesso em: 28 out 2017.

HARVEY, D. (2005). A produção capitalista do espaço. São Paulo, Annablume.

KLINK, J. (2013). "A escalaridade e a espacialidade do (novo) desenvolvimentismo: uma exploração conceitual para o debate". In: BRANDÃO, C.; SIQUEIRA, H. Pacto federativo, integração nacional e desenvolvimento regional. São Paulo, Fundação Perseu Abramo.

LOBO, C. A. (2000). Os terminais portuários privativos na lei n. 8.630/93. Rio de Janeiro. Revista de Direito Administrativo, Renovar, v. 220. Disponível em: <http://www.loboeibeas.com.br/ archives/1665>. Acesso em: 11 jul 2017.

MARQUES NETO, F. A. (2009). Bens públicos: função social e exploração econômica: o regime jurídico das utilidades públicas. Belo Horizonte, Fórum.

MOREIRA, F. A. (2018). Terras de exclusão, portos de resistência: um estudo sobre a função social das terras da União. Tese de doutorado. São Paulo, Universidade de São Paulo.

NOBRE, M. (2013). Imobilismo em movimento. Da abertura democrática ao governo Dilma. São Paulo, Companhia das Letras.

NUNES, E. (2010). A gramática política do Brasil-Clientelismo, corporativismo e insulamento burocrático. Rio de Janeiro, Garamond.

O ESTADO DE S.PAULO (2008). Santos Brasil se interessa na expansão do porto. 26 ago. Disponível em: <http://revistacafeicultura.com.br/index.php?tipo=ler\&mat=16322>. Acesso em: 15 out 2017.

(2013). Depois de operação, Antaq pune Codesp por beneficiar Miranda. Estadão, 3 de jan. Disponível em: <http://politica.estadao.com.br/noticias/eleicoes,depois-de-operacao-antaqpune-codesp-por-beneficiar-miranda-imp-,980006>. Acesso em: 24 ago 2017.

OLMOS, F. (2009). O zoneamento da Baixada Santista. O Eco, 3 fev. Disponível em: <http://www.oeco. org.br/colunas/fabio-olmos/20906-o-zoneamento-da-baixada-santista/>. Acesso em: 14 mar 2017.

PAULANI, L. (2010). “Capitalismo financeiro, estado de emergência econômico e hegemonia às avessas no Brasil”. In: OLIVEIRA, F.; BRAGA, R.; RIZEK, C. (orgs.). Hegemonia às avessas: economia, política e cultura na Era da servidão financeira. São Paulo, Boitempo. 
PINTO, E. (2013). “Dinâmica econômica e regional no Brasil dos anos 2000: efeito China, desconcentração espacial e bloco no poder". In: BRANDÃO, C.; SIQUEIRA, H. Pacto federativo, integração nacional e desenvolvimento regional. São Paulo, Fundação Perseu Abramo.

PIRES, F. (2012). Concessões prejudicam duplicação de porto de Santos. Vi o mundo [originalmente publicada no jornal Valor Econômico], 30 nov. Disponível em: <http://www.viomundo.com.br/ voce-escreve/o-publico-o-privado-e-a-ilha-de-gilberto-miranda.html>. Acesso em: 15 jun 2016.

REVISTA PORTUÁRIA (2008). “Libra quer integrar estudos do projeto Barnabé-Bagres”. Portal Logweb. 16 jul. Disponível em: <http://www.logweb.com.br/libra-quer-integrar-estudos-do-projetobarnabe-bagres/>. Acesso em: 24 ago 2016.

ROLNIK, R. (2017). Aula de erudição. Concurso para Professor Titular da FAU-USP. São Paulo, Universidade de São Paulo.

SANCHEZ, R. (2007). O Porto tem que dobrar a estrutura a cada 4 anos. A Tribuna, 23 out.

SANTOS - Câmara Municipal (1999). Lei complementar n. 359, de 1999. Disciplina o ordenamento do uso e da ocupação do solo na Área continental do município, dá nova disciplina à área de Proteção ambiental - APA, e dá outras providências. Mimeo.

(2011). Lei complementar n. 729, de 2011. Disciplina o ordenamento do uso e da ocupação do solo na Área continental do município, dá nova disciplina à área de Proteção ambiental APA, e dá outras providências. Disponível em: <https://sogi8.sogi.com.br/Arquivo/Modulo113. MRID109/Registro61816/lei\%20complementar\%20n\%C2\%BA\%20729,\%20de\%2011-07-2011. pdf> Acesso em: 12 ago 2017.

SEABRA, O. (2015). Os meandros dos rios nos meandros do poder: o processo de valorização dos rios e das várzeas do Tietê e do Pinheiros. São Paulo, Alameda.

SMA - Secretaria do Meio Ambiente do Estado de São Paulo (2013). "ZEE Baixada Santista: zoneamento ecológico-econômico - setor costeiro da Baixada Santista"; Organização Luiz Roberto Numa de Oliveira; Equipe técnica Beatriz Santos Caio et al. São Paulo, SMA.

STEINBERGER, M. (org.) (2006). Território, ambiente e políticas públicas. Brasília, Editora ELG.

TECNOLOGÍsTICA ONLINE (2006). Porto de Santos terá novo Terminal de Exportação de Veículos. Tecnologística On-line. 27 abr. Disponível em: <http://www.tecnologistica.com.br/portal/ noticias/34661/portodesantosteranovoterminaldeexportacaodeveiculos/cadastro.php>. Acesso em: 19 jun 2017.

VALOR ECONÔMICO (2008). Portos - Mudanças dividem empresários e podem parar na Justiça. Revista Cafeicultura. Disponível em: <http://revistacafeicultura.com.br/index. php?tipo=ler\&mat=16250\&portos---mudancas-dividem-empresarios-e-podem-parar-na-justica. html>. Acesso em: 31 jul 2017.

(2010a). “Barnabé Bagres garante a expansão do Porto”. Portos e Navios. 20 set. Disponível em: <https://www.portosenavios.com.br/noticias/portos-e-logistica/5175-barnabe-bagres-garantea-expansao-do-porto>. Acesso em: 15 jun 2016.

(2010b). "Novo plano diretor vai redesenhar Santos". Portal Marítimo. 20. set. Disponível em:<http://www.portalmaritimo.com/2010/09/20/novo-plano-diretor-vai-redesenharsantos-2/>. Acesso em: 15 jun 2016. 
VALOR ECONÔMICO (2017). "Diretor da Rodrimar liga Loures e Temer a porto de Santos, diz revista". Valor, 12 jun. Disponível em: <http://www.valor.com.br/politica/5002092/diretor-da-rodrimarliga-loures-e-temer-porto-de-santos-diz-revista>. Acesso em: 27 out 2017.

WERNECK, M. (2008.) Privatização dos portos: análise da controvérsia. TCC. Rio de Janeiro, Pontifícia Universidade Católica do Rio de Janeiro.

Texto recebido em $5 / \mathrm{mar} / 2020$

Texto aprovado em 29/abr/2020 